PNL-SA-25506

\title{
IRRADIATION-ASSISTED STRESS CORROSION CRACKING CONSIDERATIONS AT TEMPERATURES BELOW $288^{\circ} \mathrm{C}$
}

\author{
E. P. Simonen \\ R. H. Jones \\ S. M. Bruemmer
}

March 1995

Presented at the

Corrosion 1995 Conference

March 26-31, 1995

Orlando, Florida

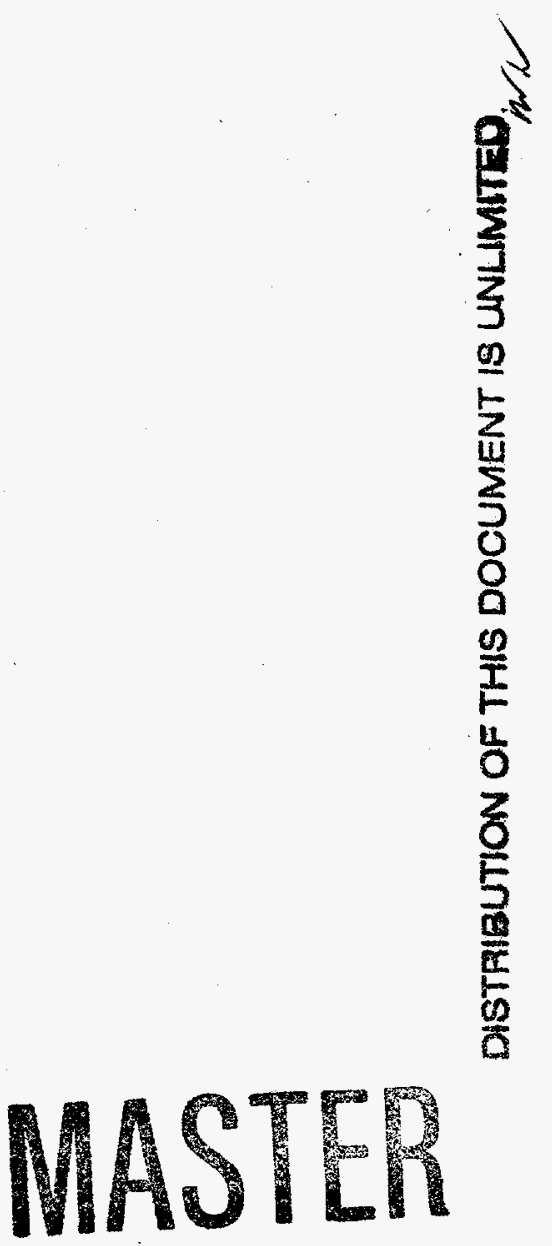

\section{DISCLAIMER}

This report was prepared as an account of work sponsored by an agency of the United States Government. Neither the United States Government nor any agency thereof, nor any of their employees, makes any warranty, express or implied, or assumes any legal liability or responsibility for the accuracy, completeness, or usefulness of any information, apparatus, product, or process disclosed, or represents that its use would not infringe privately owned rights. Reference herein to any specific commercial product, process, or service by trade name, trademark, manufacturer, or otherwise does not necessarily constitute or imply its endorsement, recommendation, or favoring by the United States Government or any agency thereof. The views and opinions of authors expressed herein do not necessarily state or reflect those of the United States Government or any agency thereof. 


\section{DISCLAIMER}

Portions of this document may be illegible in electronic image products. Images are produced from the best available original document. 


\title{
IRRADIATION-ASSISTED STRESS CORROSION CRACKING CONSIDERATIONS AT TEMPERATURES BELOW $288^{\circ} \mathrm{C}$
}

\author{
E. P. Simonen, R. H. Jones, and S. M. Bruemmer \\ Pacific Northwest Laboratory \\ Richland, WA 99352
}

\begin{abstract}
Irradiation-assisted stress corrosion cracking (IASCC) of austenitic stainless steel (SS) is known to occur in water environments at temperatures near $288^{\circ} \mathrm{C}$, but very little information exists to indicate susceptibility as temperatures are reduced. Potential low-temperature behavior is assessed based on the temperature dependencies of intergranular (IG) SCC in the absence of irradiation, radiation-induced segregation (RIS) at grain boundaries and micromechanical deformation mechanisms. IGSCC of sensitized SS in the absence of irradiation exhibits high growth rates at temperatures down to $200^{\circ} \mathrm{C}$ under conditions of anodic dissolution control, while analysis of hydrogen-induced cracking suggests a peak crack growth rate near $100^{\circ} \mathrm{C}$. Hence from environmental considerations, IASCC susceptibility appears to remain likely as water temperatures are decreased.

Irradiation experiments and model predictions indicate that RIS also persists to low temperatures. Chromium depletion may be significant at temperatures below $100^{\circ} \mathrm{C}$ for irradiation doses greater than 10 displacements per atom (dpa). Macromechanical effects of irradiation on strength and ductility are not strongly dependent on temperature below $288^{\circ} \mathrm{C}$. However, temperature does significantly affect radiation effects on SS microstructure and micromechanical deformation mechanisms. The critical conditions for material susceptibility to IASCC at low temperatures may be controlled by radiation-induced grain boundary microchemistry, strain localization due to irradiation microstructure and irradiation creep processes.
\end{abstract}

Keywords: Irradiation assisted stress corrosion cracking, temperature dependence, radiation-induced segregation, deformation, intergranular stress corrosion cracking.

\section{INTRODUCTION}

Irradiation-assisted stress corrosion cracking (IASCC) occurs above a critical neutron fluence in light-water reactor (LWR) water environments at $288^{\circ} \mathrm{C} .1-5$ The fluence 
threshold depends on complex environmental and material conditions, but is most clearly established for Type 304 stainless steel (SS) in oxygen-containing water. Cracking has not been extensively evaluated at lower temperatures, but is of interest for the startup and shutdown of LWRs and in the design of fusion reactors. Many temperature-dependent processes are expected to affect IASCC susceptibility. This paper examines temperature-dependent material and environmental parameters that may influence IASCC. Processes that are known to affect intergranular (IG) SCC in the absence of irradiation are evaluated along with temperature-dependent mechanisms for radiation effects on material susceptibility.

\section{STRESS CORROSION OF UNIRRADIATED STAINLESS STEELS}

Unirradiated sensitized SSs typically exhibit a peak crack growth rate at a temperature near $200^{\circ} \mathrm{C}$, as shown by Andresen. 6 Maximum crack velocities were established by slow strain rate tests (SSRT) and fracture mechanics tests under controlled environmental and material conditions. The IGSCC temperature dependence results from a complex interaction among corrosion potential, solution chemistry, and chemical equilibria (e.g., pH, ionization and solubility). Above $200^{\circ} \mathrm{C}$, crack growth velocity increases with increasing temperature for high-oxygen water, but decreases with temperature as $\mathrm{O}_{2}$ is reduced to $0.2 \mathrm{ppm}$ as illustrated in Figure 1. The temperature dependence for crack growth rate is parallel to the temperature dependence for $\mathrm{Fe}$ solubility in the lower oxygen case. 6 At temperatures below $200^{\circ} \mathrm{C}$, the crack growth velocity decreases with decreasing temperature for both environments. The temperature dependence at low temperatures does not reflect any single dominant kinetic process.

The evidence supporting a decreasing crack growth rate for temperatures below $200^{\circ} \mathrm{C}$ is extensive. $6-10$ On the other hand, the evidence supporting a decreasing crack growth rate for temperatures above $200^{\circ} \mathrm{C}$ is sometimes contradictory. These contradictions can, in most cases, be resolved through consideration of high or uncontrolled concentrations of oxygen, impurities, or both. Attempts have been made to assign activation energies to crack growth rate and to relate the energies to transport in aqueous solutions (as compared to oxide films). However, the complexity of the temperature-dependent processes likely precludes assigning a single dominant activation mechanism. 6

Impurities, such as sulfates and chlorides, strongly increase crack growth rates 11 at low temperatures, as shown in Figure 1. Crack growth rates in deionized water (DIW) have a maximum rate of about $4 \times 10^{-6} \mathrm{~mm} / \mathrm{s}$, whereas in impure water, they can exceed $10-5 \mathrm{~mm} / \mathrm{s}$. For sensitized $304 \mathrm{SS}$, sulfate additions are more aggressive than chloride addition at temperatures less than $200^{\circ} \mathrm{C} .6$ Aggression of the two impurities is nearly equal above $250^{\circ} \mathrm{C}$. Accelerating effects caused by impurities can result in crack growth rates at about $60^{\circ} \mathrm{C}$ that are comparable to and even greater than growth 
rates at high temperatures.

Material and test conditions can also strongly impact cracking susceptibility and growth rates. The extent of grain boundary $\mathrm{Cr}$ depletion (degree of sensitization) controlled by bulk carbon contents and heat treatments significantly influences IG crack initiation and growth.12 Material strength and surface condition can increase SCC susceptibility. For example, shot peening can promote cracking at low temperatures by reducing the initiation time for cracking. Finally, IGSCC also depends on test conditions such as strain rate. Critical grain boundary $\mathrm{Cr}$ concentrations for IG cracking in high-temperature water have been shown to increase from $~ 14 \%$ to $17 \%$ when the test strain rate was reduced from $1 \times 10^{-6} \mathrm{~s}^{-1}$ to $2 \times 10^{-7} \mathrm{~s}^{-1} .13$

The examples reviewed above have emphasized dissolution-controlled cracking mechanisms expected for sensitized materials in oxidizing environments. However, hydrogen may play.an important role in low-temperature IGSCC and has been proposed as contributing to IASCC. 5 Hydrogen can become enriched in SSs from several sources including corrosion reactions and irradiation-induced transmutations. A three-fold increase in the hydrogen content was detected for a 304SS irradiated to fluences from $1.9 \times 1018 \mathrm{n} / \mathrm{cm}^{2}(E>1 \mathrm{MeV})$ to $9 \times 1021 \mathrm{n} / \mathrm{cm}^{2}$ (E> $\left.1 \mathrm{MeV}\right)$ in hightemperature water. 14 Internal hydrogen concentrations can reach much higher levels during irradiations with a fusion neutron spectrum and impact subcritical crack growth. 15 Hydrogen-induced crack growth rates were predicted to increase with temperature reaching a maximum rate near $100^{\circ} \mathrm{C}$, then decrease sharply at higher temperatures as shown in Figure 2.

\section{SCC OF STAINLESS STEELS IRRADIATED AT LOW TEMPERATURES}

Only a few experiments have addressed stress corrosion cracking of irradiated alloys in water at less than $288^{\circ} \mathrm{C}$. The limited studies indicate that SCC can occur in postirradiated SSs at lower temperatures, particularly at test temperatures down to $200^{\circ} \mathrm{C}$. However, the observed IG cracking susceptibility appears to be reduced as summarized below. Crack growth has only been characterized by SSRTs at strain rates near $10^{-7} \mathrm{~s}^{-1}$, considerably faster than the creep rates anticipated for in-reactor component cracking.

\section{Low-Temperature Dependence for Low-Dose Neutron Exposure}

Irradiated 304SSs from a Savannah River Reactor tank have been tested for SCC susceptibility. 16 Specimens were exposed to about 1 displacement per atom (dpa) of neutron irradiation at $150^{\circ} \mathrm{C}$. One dpa corresponds to about $7 \times 1020 \mathrm{n} / \mathrm{cm}^{2}(E>1$ $\mathrm{MeV}$ ). Tests were conducted in water at $105^{\circ} \mathrm{C}$ with a pH of 5 and with an impure (compared to LWR) water chemistry plus 2 to $6 \mathrm{ppm} \mathrm{O}$. IASCC was not observed during post-irradiation SSRTs (strain rates $>10^{-7} \mathrm{~s}^{-1}$ ). 
Significant IG fracture was observed in high purity and commercial purity grades of $304 \mathrm{SS}$ after irradiation at $50^{\circ} \mathrm{C}$ to a fluence of $3 \times 10^{21} \mathrm{n} / \mathrm{cm}^{2}$ (E>1 MeV) i.e., 4 dpa. 17 The IG fracture was induced using SSRT at $2.5 \times 10^{-7} \mathrm{~s}^{-1}$ in $288^{\circ} \mathrm{C}$ water containing 32 $\mathrm{ppm}$ dissolved oxygen and having a conductivity of $0.1 \mu \mathrm{S} / \mathrm{cm}$. Similar tests of nuclear grade 316 stainless steel showed no IG fracture.

\section{Low-Temperature Dependence for High-Dose Neutron Exposure}

A 316 stainless steel alloy was irradiated to $8 \mathrm{dpa}$, and SCC evaluated using SSRTs, at a series of temperatures. 18 The higher temperature tests (irradiations at $330^{\circ} \mathrm{C}$ or $400^{\circ} \mathrm{C}$, SSRTs at $300^{\circ} \mathrm{C}$ ) showed more IG cracking compared to the lower temperature (irradiations and SSRTs at $60^{\circ} \mathrm{C}$ or $200^{\circ} \mathrm{C}$ ) tests. Specifically, the fracture morphology after SSRTs indicated no IGSCC at $60^{\circ} \mathrm{C}$, mixed mode at $200^{\circ} \mathrm{C}$ with some IG features, and predominantly IG fracture for SSs irradiated at $330^{\circ} \mathrm{C}$ or $400^{\circ} \mathrm{C}$.

Low-temperature SSRTs were also conducted on a 316 stainless steel alloy irradiated to $40 \mathrm{dpa}$ in an experimental fast breeder reactor at $424^{\circ} \mathrm{C} .19$ Post-irradiation tests showed an increase in SCC with temperature. Fracture surface analysis indicated that the percent SCC (IG plus transgranular) was $0 \%, 5 \%$ and $25 \%$ at $60^{\circ} \mathrm{C}, 200^{\circ} \mathrm{C}$ and $300^{\circ} \mathrm{C}$, respectively. Uniform elongation decreased from $6 \%$ at $60^{\circ} \mathrm{C}$ to $0.4 \%$ at $300^{\circ} \mathrm{C}$. A SSRT in air did not exhibit the loss in ductility nor IG fracture measured for the $300^{\circ} \mathrm{C}$ test in water.

\section{Proton Irradiation Behavior}

Proton irradiation and post-irradiation testing of an ultra-high-purity (UHP) 304LSS has suggested a decrease in IASCC susceptibility as the irradiation temperature was decreased from 400 to $200^{\circ} \mathrm{C} .20$ IASCC susceptibility was indicated by the number of IG cracks on the irradiated surface of $288^{\circ} \mathrm{C}$ SSRT samples. IGSCC was documented after the $200^{\circ} \mathrm{C}$ irradiation, but much more extensive IG cracking was seen after a $400^{\circ} \mathrm{C}$ irradiation. Specimens were irradiated to $1 \mathrm{dpa}$ and tested at a strain rate of $3.6 \times 10^{-7} \mathrm{~s}^{-1}$ in $2 \mathrm{ppm} \mathrm{O}_{2}$ water at $288^{\circ} \mathrm{C}$ for both irradiated conditions.

\section{TEMPERATURE DEPENDENCE OF IRRADIATED MATERIAL CHARACTERISTICS}

For the purposes of this review, the influence of radiation on material characteristics will be divided into those that affect grain boundary microchemistry and those that affect grain boundary mechanical behavior. Grain boundary RIS (e.g., Cr depletion) decreases with irradiation temperature below $288^{\circ} \mathrm{C}$, because of reduced survival of radiation produced point defects, i.e. vacancies and interstitials. Significant changes in interfacial chemistries cannot be produced without the creation and relatively longrange diffusion of these point defects. 
Irradiation affects mechanical behavior on a macro- and micromechanical level. On a macromechanical level, irradiated yield strengths have a weak temperature dependence below $288^{\circ} \mathrm{C}$ and uniform ductilities during SSRT in water exhibit a modest improvement with decreasing temperatures below $288^{\circ} \mathrm{C}$. Less is known about irradiation effects on the deformation micromechanics, in particular, the stressinduced interactions between network dislocations, irradiation damage and grain boundaries. Temperature-dependent processes will affect strain localization during deformation and dislocation interactions with irradiation-induced microstructural defects. Irradiations at $60^{\circ} \mathrm{C}$ versus $300^{\circ} \mathrm{C}$ will produce significantly different microstructures and impact properties such as work hardening and irradiation creep.

\section{RIS Model Predictions and Experimental Results}

Model predictions based on the inverse-Kirkendall mechanism and reference parameters recommended by Perks et al.21 have been used to evaluate major alloying element segregation. The predicted temperature dependence at low temperatures 22 is controlled by mutual recombination of irradiation-produced self interstitials and vacancies. In particular, RIS temperature dependence is a function of the assumed migration kinetics of the slowest defect, namely, vacancies. The present study uses measured temperature dependence of grain boundary $\mathrm{Cr}$ depletion and $\mathrm{Ni}$ enrichment induced by ion or proton irradiation to establish the expected RIS temperature dependence and to extrapolate to neutron irradiation at low temperatures. The predicted grain boundary concentrations were convoluted to take into account the field-emission-gun scanning-transmission-electron microscopy (FEG-STEM) beam profile width. The inverse-Kirkendall predictions can then be compared directly to the FEG-STEM grain boundary measurements.

\section{Ion Irradiation}

The effect of irradiation on grain boundary microchemistry in a microcrystalline stainless steel was characterized as a function of temperature $\left(180\right.$ to $\left.350^{\circ} \mathrm{C}\right)$ with $\mathrm{Ni}^{++}$ ion irradiation and FEG-STEM analysis. Irradiations were conducted at a displacement rate of $5 \times 10^{-3} \mathrm{dpa} / \mathrm{s}$ to a dose of $10 \mathrm{dpa}$. Irradiation procedures and material descriptions have been reported previously. 23 Specimens were analyzed using a Vacuum Generator HB501 dedicated STEM and an energy dispersive X-ray spectrometer. A through thickness resolution of $3 \mathrm{~nm}$ was obtained for microchemical analysis. The matrix $\mathrm{Fe}, \mathrm{Cr}$ and $\mathrm{Ni}$ concentrations were assumed to be 59, 21, and 20 at $\%$ to be in accord with matrix concentrations measured with FEG-STEM analysis.

Temperature dependence of the measured grain boundary $\mathrm{Cr}$ and $\mathrm{Ni}$ concentrations are illustrated in Figures 3(a) and (b), respectively. RIS is not effectively suppressed at $10 \mathrm{dpa}$ until temperatures are lowered below $300^{\circ} \mathrm{C}$. Model predictions of grain boundary $\mathrm{Cr}$ and $\mathrm{Ni}$ concentrations are also shown in Figure 3. The effect of the assumed vacancy migration energy is demonstrated. A value of $1.28 \mathrm{eV} 24$ is 
commonly assumed for austenitic alloys, although annealing measurements on SSs indicate $1.17 \mathrm{eV} 25$. In the present analysis, $1.15 \mathrm{eV}$ is considered a reasonable estimate based on defect physics experiments. $25 \mathrm{~A}$ value of $1.0 \mathrm{eV}$ is included to illustrate sensitivity to lower values of the vacancy migration energy and indicate the value for a better empirical fit to the RIS measurements. The damage efficiency for producing freely migrating defects by $\mathrm{Ni}$ ions is expected to be a few percent 26 and $3 \%$ is used in Figure 3.

\section{Proton Irradiation}

Similar to ion irradiation, proton irradiation 27 has been used to document the temperature dependence of RIS in an austenitic stainless alloy. Grain boundary $\mathrm{Cr}$ and $\mathrm{Ni}$ concentrations measured by Auger electron spectroscopy (AES) are shown in Figure 4. Dose level was considerably less for the proton study at $0.5 \mathrm{dpa}$, but a strong temperature dependence was observed as irradiation temperatures dropped below $400^{\circ} \mathrm{C}$. Model predictions accurately track data using a vacancy migration energy of $1.15 \mathrm{eV}$ and a damage efficiency of $10 \%$ for protons. Therefore, the model qualitatively predicts the temperature dependence for both ion irradiation and proton irradiation assuming the same material parameters. The apparent vacancy migration energy is in the range of 1.0 to $1.15 \mathrm{eV}$.

\section{Neutron Irradiation Predictions}

Comparable temperature-dependent RIS data is not available for neutron-irradiated SSs, but prior work 28 has shown that the inverse-Kirkendall model can reasonably predict $\mathrm{Cr}$ depletion as a function of dose at $288^{\circ} \mathrm{C}$. Predicted low-temperature segregation behavior is presented in Figure 5 for temperatures from $50^{\circ} \mathrm{C}$ to $300^{\circ} \mathrm{C}$ and for doses up to $30 \mathrm{dpa}$. The example calculation assumes a fusion reactor dose rate of $3 \times 10^{-7} \mathrm{dpa} / \mathrm{s}$, a vacancy migration energy of $1.15 \mathrm{eV}$, and a damage efficiency of $1 \%$. Significant $\mathrm{Cr}$ depletion is predicted during neutron irradiation at low temperatures, for example, $\mathrm{Cr}$ levels drop to less than $14 \%$ at $100^{\circ} \mathrm{C}$ as the dose exceeds $10 \mathrm{dpa}$.

\section{Low Temperature Deformation}

The effect of irradiation on deformation of austenitic SSs is evident in its macro- and micromechanical behavior. Yield strength and ductility are strongly affected by irradiation and test temperature. In addition, dynamic irradiation and the evolving microstructural changes alter the micromechanics of deformation and may play a significant role in IASCC.

\section{Strength}

Yield strength of an austenitic SS increases with increasing irradiation fluence, and has a maximum effect when irradiation exposure and mechanical testing is conducted at $-300^{\circ} \mathrm{C}$. A typical strength dependence 29 on temperature for a highly irradiated steel is shown in Figure 6 . Radiation strength rapidly decreases with increasing 
temperature above $300^{\circ} \mathrm{C}$, but decreases weakly with decreasing temperature below $300^{\circ} \mathrm{C}$. The temperature dependence of the microstructural components that cause hardening 30 at $7 \mathrm{dpa}$ is shown in Figure 7 . Yield strength in Figure 7 is predicted to be nearly independent of temperature below $300^{\circ} \mathrm{C}$. However, the relative importance of hardening components does change. At temperatures less than $300^{\circ} \mathrm{C}$, the Frank loop influence on strength decreases, while the black dot component increases. IGSCC processes that depend on the material strength level should not be strongly affected by temperature, but processes that depend on microstructural details may be strongly dependent on temperature.

\section{Ductility}

Tensile ductility decreases with increasing irradiation fluence and reaches a minimum near $300^{\circ} \mathrm{C}$ at high irradiation dose. Temperature effects on uniform elongation29 are shown in Figure 6 for an irradiated SS. The increase in elongation at temperatures above and below $300^{\circ} \mathrm{C}$ are consistent with the observed decrease in strength noted in Figure 6. Results for a specific irradiation series on a 316-type SS31 are shown in Figure 8. The data reflect the lack of temperature dependence for irradiated yield strength, and an increase in ductility with temperature below $300-400^{\circ} \mathrm{C}$. A comparison of uniform and total elongation indicates that work hardening is negligible near $60^{\circ} \mathrm{C}$, i.e., the uniform elongation is nearly equal to the total elongation. Mechanical behavior at low irradiation and test temperatures $\left(\leq 150^{\circ} \mathrm{C}\right)$ is quite different than behavior at high irradiation and test temperatures $\left(\geq 300^{\circ} \mathrm{C}\right)$.

\section{Deformation and Fracture Modes}

Irradiation creep can enhanced deformation rates and stress relaxation during neutron exposure. Irradiation creep rates of $\sim 2 \times 10^{-10} \mathrm{~s}^{-1}$ have been measured 32 in stainlessalloy, helical springs stressed to $100 \mathrm{MPa}$ at $280^{\circ} \mathrm{C}$. Similarly, creep strain greater than $10^{-3}$ was measured 33 for a $25 \%$ cold-worked, 316 -type SS at $60^{\circ} \mathrm{C}$. The corresponding creep rate assuming a steady-state creep rate is about $2 \times 10^{-10} \mathrm{~s}^{-1}$. A low-temperature creep mechanism based on transient survival of point defects was proposed to account for the unexpected large creep strain at $60^{\circ} \mathrm{C}$. Model predictions for an annealed SS indicated 34 that the steady-state irradiation creep rate can vary from $10^{-9} \mathrm{~s}^{-1}$ at $300^{\circ} \mathrm{C}$ to $10^{-12} \mathrm{~s}^{-1}$ at $60^{\circ} \mathrm{C}$. These measurements and model predictions suggest that in-core, irradiation creep will influence temperaturedependent stress relaxation, and the micromechanics of localized deformation.

Post-irradiation, SSRTs are typically run at strain rates faster than $10^{-7} \mathrm{~s}^{-1}$, whereas incore strain rates controlling IASCC initiation and propagation are probably as low as 10-10 $\mathrm{s}^{-1}$. Bulk deformation at such low rates may localize strain and stress concentration at, and allow sliding of, grain boundaries even at LWR temperatures. The stress and temperature dependence of the fracture behavior in 304SS irradiated to a high-fast-neutron fluence as shown in Figure 9.35 A region of unstable grain boundary crack propagation can be seen which reaches temperatures below $300^{\circ} \mathrm{C}$ 
and is promoted at lower stresses and lower strain rates. Boundaries for the individual fracture mode regions are diffuse and are dependent on irradiation and test conditions. A transition from transgranular to IG fracture as strain rates were decreased to $\sim 10^{-6} \mathrm{~s}^{-1}$ was reported 36 for irradiated SS during SSRTs in $300^{\circ} \mathrm{C}$ argon. This "mechanical" failure along grain boundaries in irradiated SSs at this low temperature has not be reproduced. The few post-irradiation tests at strain rates down to $\sim 10^{-7} \mathrm{~s}^{-1}$ that have been conducted indicate that the water environment is required for IG fracture. However, SSRTs have not been performed at strain rates approaching in-core rates of $10^{-9}$ to $10^{-10} \mathrm{~s}^{-1}$.

Irradiation microstructures are known to promote localized deformation in SSs. Dislocation channeling has been observed for post-irradiation and in-reactor deformation. Dislocation channeling and channel fracture has been documented 37 at intermediate temperatures, about 300 to $400^{\circ} \mathrm{C}$, at high neutron fluence and at high stress (strain rates appropriate for measuring tensile properties) as illustrated in Figure 9. Stainless alloys irradiated by proton 38 or by heavy ions 39 also exhibit dislocation channels after SSRTs at $288^{\circ} \mathrm{C}$. Ion-irradiated materials (to a dose of $5 \mathrm{dpa}$ ) show a transition to predominately twinning deformation as test temperatures are reduced to ambient. The above evidence documents the highly planar deformation that occurs in irradiated austenitic SSs. This localized deformation mode will create high stresses and strains at grain boundaries and may contribute to IASCC.

\section{CONCLUSIONS}

Temperature effects on IASCC are expected from the IGSCC behavior of unirradiated SSs and from changes in irradiation response with temperature. The temperature dependence for IG cracking in water emerges because of the complex thermodynamic and kinetic processes that compete during concurrent corrosion and deformation. In the absence of irradiation, IG cracking in sensitized materials is most strongly promoted at temperatures near $200^{\circ} \mathrm{C}$. An evaluation of possible influences of hydrogen embrittlement has suggested that the maximum hydrogen-induced crack growth rates may occur near $100^{\circ} \mathrm{C}$. Therefore, unirradiated cracking studies suggest opportunities for cracking at temperatures below $288^{\circ} \mathrm{C}$. The primary effects of irradiation on material characteristics is to change matrix microstructures, grain boundary microchemistries and subsequent micro- and macro-mechanical properties.

An analysis of the temperature dependence for RIS indicated that segregation is reduced, but not eliminated, at temperatures below $288^{\circ} \mathrm{C}$. Particularly at highirradiation exposures, low-temperature RIS may produce a sufficient degree of $\mathrm{Cr}$ depletion and material susceptibility to cause IASCC. Irradiation temperature also affects mechanical behavior. With decreasing temperature, the macromechanics of irradiation strengthening and irradiation-induced ductility loss are only moderately reduced. However, the irradiated SS microstructure and micromechanical 
deformation characteristics do change with decreasing temperature. An important consideration that has not been effectively evaluated is the influence of very slow strain rates (as for irradiation creep) on deformation mode and the propensity for IG fracture. Irradiation creep rates are significant at $288^{\circ} \mathrm{C}$ and have been measured at temperatures as low as $60^{\circ} \mathrm{C}$. These in-core deformation rates are many orders of magnitude slower than commonly used SSRTs and may play a critical role in the mechanisms controlling IASCC.

\section{ACKNOWLEDGEMENTS}

This research was supported by the Materials Sciences Branch, Office of Basic Energy Sciences, and the Office of Fusion Energy, U.S. Department of Energy. Pacific Northwest Laboratory is operated for the U.S. DOE by Battelle Memorial Institute under Contract DE-AC06-76RLO 1830.

\section{REFERENCES}

1. W. L. Clarke and A. J. Jacobs, "Effect of Radiation Environment on SCC of Austenitic Materials," Proc. 1st Int. Symp. on Environmental Degradation of Materials in Nuclear Power Systems - Water Reactors, J. T. A. Roberts and W. Berry, Eds., Myrtle Beach, SC, August 1989, NACE, Houston, TX, 1984, p. 451461.

2. P. L. Andresen, F. P. Ford, S. M. Murphy, and J. M. Perks, "State of Knowledge of Radiation Effects on Environmental Cracking in Light Water Reactor Core Materials," Proc. 4th Int. Symp. on Environmental Degradation of Materials in Nuclear Power Systems - Water Reactors, D. Cubicciotti, Ed., Jekyll Island, GA, August 1989, NACE, Houston, TX, 1990, p. 1-83.

3. J. L. Nelson and P. L. Andresen, "Review of Current Research and Understanding of Irradiation-Assisted Stress Corrosion Cracking," Proc. 5th Int. Symp. on Environmental Degradation of Materials in Nuclear Power Systems Water Reactors, E. P. Simonen D. Cubicciotti, Eds., Monterey, CA, American Nuclear Society, La Grange Park, IL, 1992, p. 10.

4. $\quad$ P. L. Andresen, "Irradiation-Assisted Stress Corrosion Cracking," Stress Corrosion Cracking, ed. R. Jones, ASM International, Metals Park, OH, 1992.

5. P. Scott, J. Nucl. Mater., 211, 1994, p. 101.

6. P. L. Andresen, Corr. Science, Vol. 49, No. 9, p. 714. 
7. F. P. Ford, "Mechanisms of Environmental Cracking in Systems Peculiar to the Power Generation Industry," EPRI Contract RP1332-1, EPRI NP2589 (1982)

8. W. E. Ruther, W. K. Soppet, T. F. Kassner, Corrosion 44, 1988, p. 791.

9. E. D. Eason, J. Padmanaban, "A Model of Expected Time to Failure by IGSCC in 304 Stainless Steel," Report FAA-M-82-12-4, Failure Analysis Associates, Palo Alto, CA, 1982.

10. R. Magdowski Pedrazolli, M. O. Speidel, "Effect of Temperature on Stress Corrosion Crack Growth in Austenitic Stainless Steels Exposed to Water," paper no. 291, Corrosion/90, NACE, Houston, TX, 1990.

11. R. H. Jones and C. H. Henager, Jr., J. Nucl. Mater., 191-194, 1992, p. 1012.

12. S. M. Bruemmer, Grain Boundary Chemistry and Intergranular Fracture, Mat. Sci. Forum, Vol. 46, eds. G. S. Was and S. M. Bruemmer, Trans Tech Publ., Switzerland, 1989, p. 309.

13. S. M. Bruemmer, J. I. Cole, J. L. Brimhall, R. D. Carter and G. S. Was, "Radiation Hardening Effects on Localized Deformation and Stress Corrosion Cracking of Stainless Steels," Proc. 6th Int. Symp. on Environmental Degradation of Materials in Nuclear Power Systems - Water Reactors, R. E. Gold and E. P. Simonen, Eds., San Diego, CA, The Minerals, Metals \& Materials Society, Warrendale, PA, 1993, p. 537.

14. A. J. Jacobs, "Hydrogen Buildup in Irradiated Type-304 Stainless Steel," Influence of Radiation on Material Properties: 13th International Symposium (Part II), ASTM STP 966, F. A. Garner, C. H. Henager, Jr., and N. Igata, Eds., American Society for Testing and Materials, Philadelphia, 1987. p. 239.

15. R. H. Jones, Fusion Reactor Materials - Semiannual Report for Period Ending March 31, 1991, DOE/ER-0313/12, Oak Ridge National Laboratory, Oak Ridge TN, 1992, p. 213.

16. G. R. Caskey, R. S. Ondrejcin, P. Aldred, R. B. Davis and S. A. Wilson, Corrosion/90, paper no. 504, Las Vegas, NV, April, 1990, National Association of Corrosion Engineers, Houston, TX, 1990.

17. M. Kodama, J. Morisawa, S. Nishimura, K. Asano, S. Shima and K. Nakata, J. Nucl. Mater., 212-215, 1994, p.1509. 
18. G. E. C. Bell, T. Tsukada, K. Shiba and H. Nakajima, Fusion Reactor Materials Semiannual Report for Period Ending September 30, 1991, DOE/ER-0313/11. Oak Ridge National Laboratory, Oak Ridge, TN, 1992, p. 253.

19. T. Tsukada, S. Jitsukawa, K. Shiba, Y. Sata, I. Shibahara and H. Nakajima, J. Nucl. Mater., 207, 1993, 159.

20. J. M. Cookson, D. L. Damcott, G. S. Was and P. L. Andresen, "The Role of Microchemical and Microstructural Effects in IASCC of High Purity Austenitic Stainless Steels," Proc. 6th Int. Symp. on Environmental Degradation of Materials in Nuclear Power Systems - Water Reactors, R. E. Gold and E. P. Simonen, Eds., San Diego, CA, The Minerals, Metals \& Materials Society, Warrendale, PA, 1993, p. 573.

21. J. M. Perks and S. M. Murphy, "Modeling the Major Element Radiation-Induced Segregation in Concentrated Fe-Cr-Ni Alloys, "Proc. Materials for Nuclear Reactor Core Applications, Vol. 1, BNES, London, 1987, p. 119.

22. E. P. Simonen, R. H. Jones and S. M. Bruemmer, J. Nucl. Mater., 191-194, 1992, p. 1002.

23. S. M. Bruemmer M. D. Merz and L. A. Charlot, J. Nucl. Mater., 186, 1991, p. 13.

24. Workshop on Solute Segregation and Phase Stability During Irradiation, edited by J. O. Stiegler, J. Nucl. Mater., 83 (1979)

25. O. Dimitrov and C. Dimitrov, J. Nucl. Mat., 105 (1982) 39.

26. V. Naundorf,. J. Nucl. Mater., 182, 1991, p. 254.

27. D. L. Damcott, G. S. Was and S. M. Bruemmer, "Proton Irradiation Induced Grain Boundary Segregation in Austenitic Stainless Steel," in Proceeding of

Symposium Y, Microstructure of Irradiated Materials, I. M. Robertson, L. E. Rehn, S. J. Zinkle and W. J. Phythian, editors, Materials Research Society, Pittsburg, PA, 1995.

28. E. P. Simonen and S. M. Bruemmer, "Mechanistic Issues for Modeling Radiation-Induced Segregation," Corrosion/93, Paper No. 615, National Association of Corrosion Engineers, Houston, TX, 1993.

29. G. E. Lucas, J. Nucl. Mater., 206, 1993, p. 287.

30. M. L. Grossbeck, P. J. Maziasz and A. F. Rowcliffe, J. Nucl. Mater., 191-194, 1992, p.808. 
31. S. Jitsukawa, M. L. Grossbeck and A. Hishinuma, J. Nucl. Mater., 191-194, 1992, p. 790.

32. D. Mosedale, D. R. Harries, J. A. Hudson, G. W. Lewthwaite, and R. J. McElroy, "Irradiation Creep in Fast Reactor Core Component Materials," in Radiation Effects in Breeder Reactor Structural Materials, M. L. Bleiberg and J. W. Bennett, Eds., AIME, New York, NY, 1977, p. 209.

33. M. L. Grossbeck, M. Suzuki and L. K. Mansur, "Irradiation Creep in Austenitic Stainless Steels at 60 to $400^{\circ} \mathrm{C}$ with a Fusion Reactor He:dpa Ratio," in Effects of Radiation on Material Properties: 14th International Symposium, ASTM STP 1046, Vol. II, N. H. Packan, R. E. Stoller and A. S. Kumar, Eds., American Society for Testing and Materials, Philadelphia, 1989, p. 537.

34. J. Nagakawa, N. Yamamoto and H. Shiraishi, J. Nucl Mater., 179-181, 1991, p. 130.

35. E. E. Bloom, "Irradiation Strengthening and Embrittlement," in Proceedings of Radiation Damage in Metals, N. L. Peterson and S. D. Harkness, editors, American Society for metals, Metals Park, OH, 1975, p. 295.

36. M. P. Manahan, R. Kohli, J. Santucci and P. Sipush, Nucl. Eng. Des. 113 (1989) 297.

37. R. L. Fish J. L. Straalsund, C. W. Hunter, and J. J. Holmes, p. 149, in Effects of Radiation on Substructure and Mechanical Properties of Metals and Alloys, ASTM STP 529, American Society for Testing and Materials, Philadelphia, 1973.

38. R. D. Carter, G. S. Was, M. Atzman and S. M. Bruemmer, "Deformation Mechanisms in a Proton-Irradiated Austenitic Stainless Steel," in Proceeding of Symposium Y, Microstructure of Irradiated Materials, I. M. Robertson, L. E. Rehn, S. J. Zinkle and W. J. Phythian, editors, Materials Research Society, Pittsburg, PA, 1995.

39. J. L. Brimhall, J. I. Cole, J. S. Vetrano and S. M. Bruemmer, "Temperature and Strain-Rate Effects on Deformation Mechanisms in Irradiated Stainless Steel," in Proceeding of Symposium Y, Microstructure of Irradiated Materials, I. M. Robertson, L. E. Rehn, S. J. Zinkle and W. J. Phythian, editors, Materials Research Society, Pittsburg, PA, 1995. 


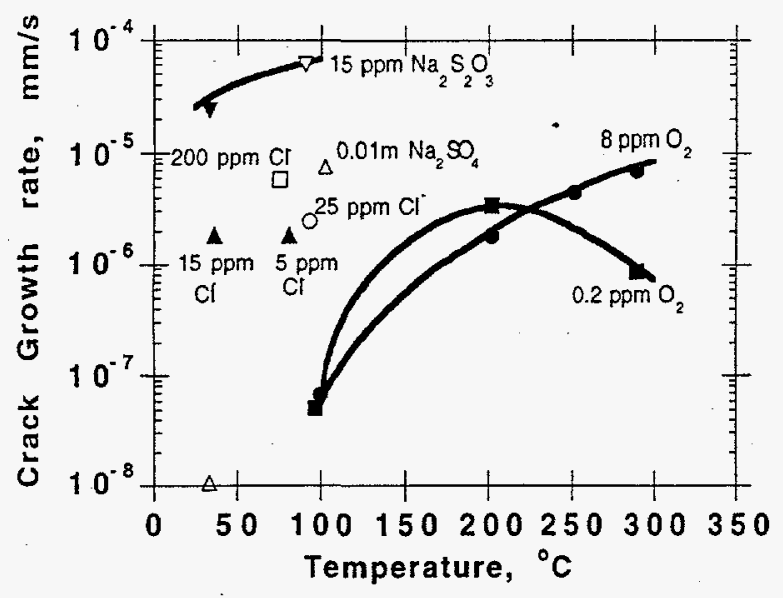

Figure 1 The temperature dependence of crack growth rate as compiled by Jones and Henager11 for sensitized steel. The curves labeled for oxygen content are obtained in deionized water. The addition of sulfates and chlorides is seen to increase the rates.

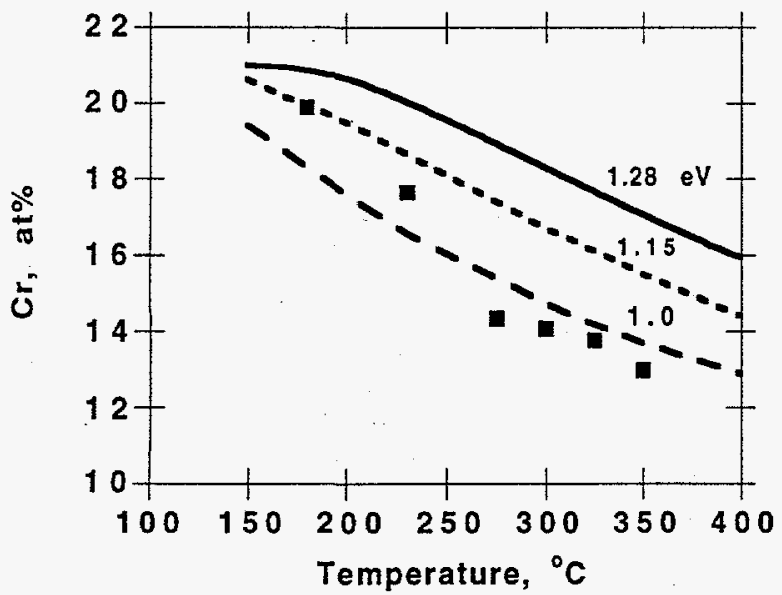

Figure $3 \mathrm{a}$ The temperature dependence of measured and predicted grain boundary $\mathrm{Cr}$ concentration induced by ion irradiation at 10 dpa.

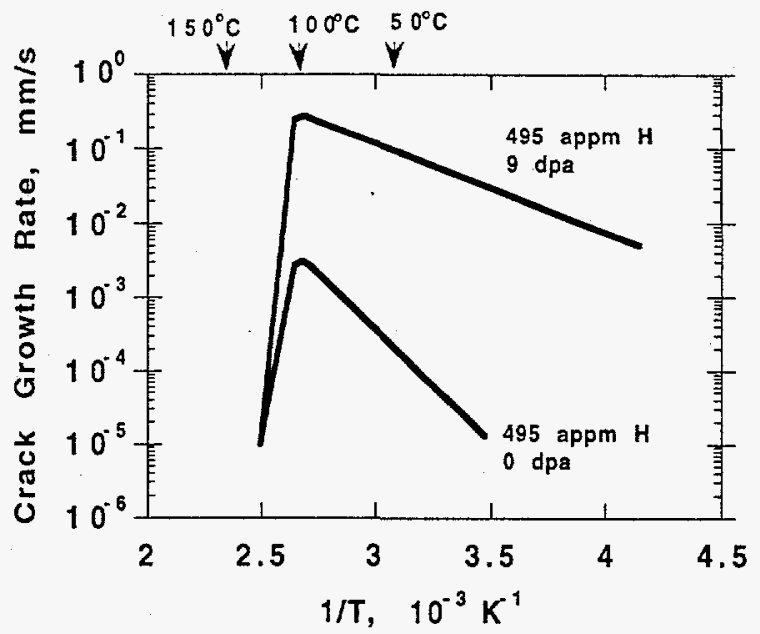

Figure 2 The temperature dependence of predicted hydrogen-induced crack growth. 15

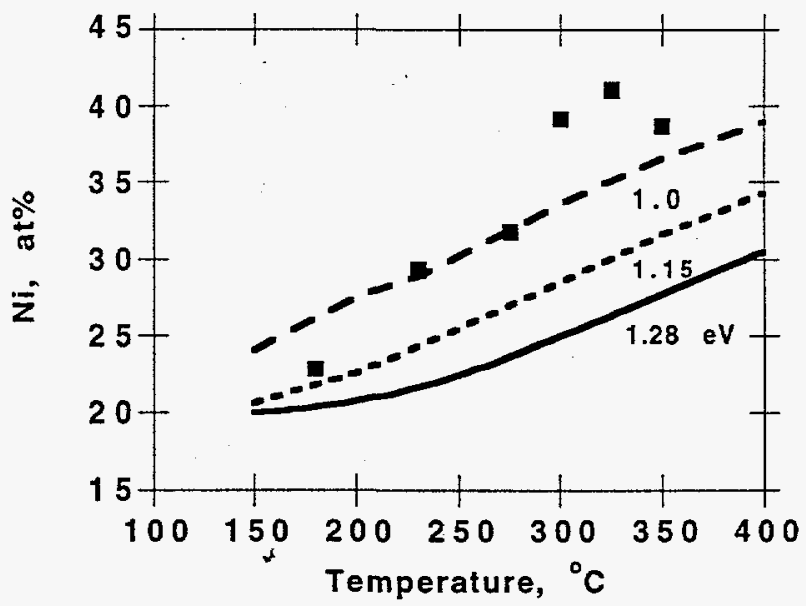

Figure $3 \mathrm{~b}$ The temperature dependence of measured and predicted grain boundary $\mathrm{Ni}$ concentration induced by ion irradiation at 10 dpa. 


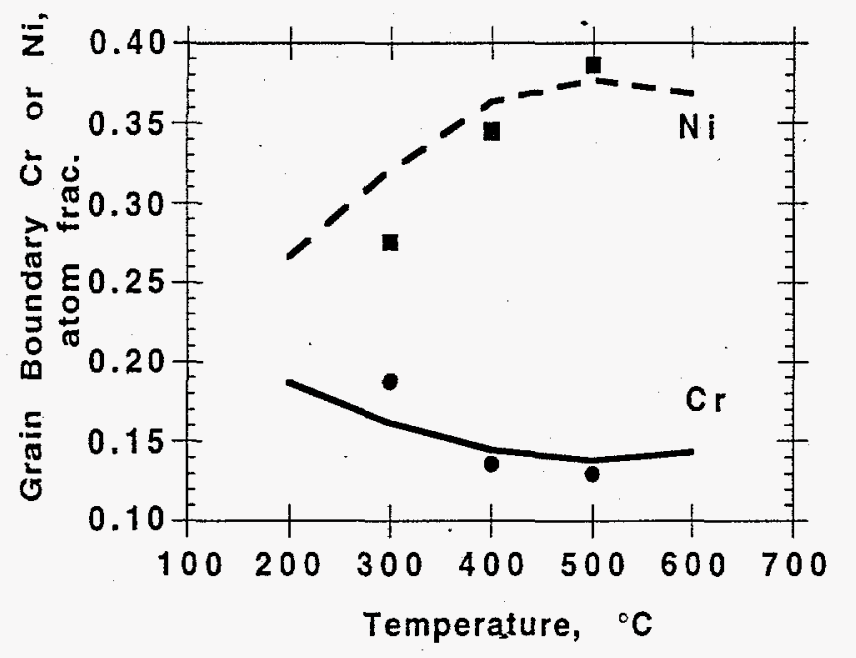

Figure 4 The temperature dependence of grain boundary $\mathrm{Cr}$ and $\mathrm{Ni}$ concentration induced by proton irradiation at $0.5 \mathrm{dpa}$.

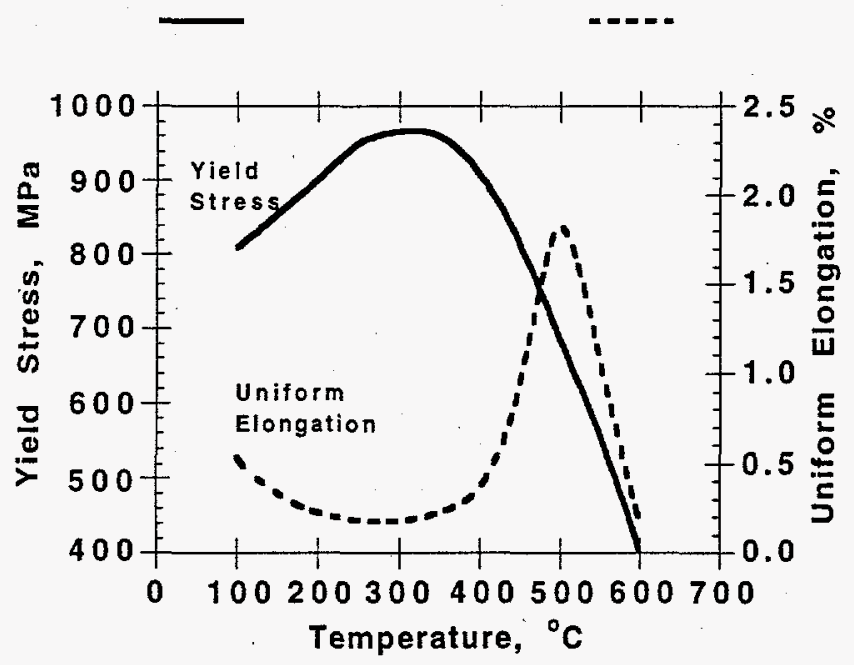

Figure 6 The trend for yield strength and uniform elongation of irradiated stainless steels. 29

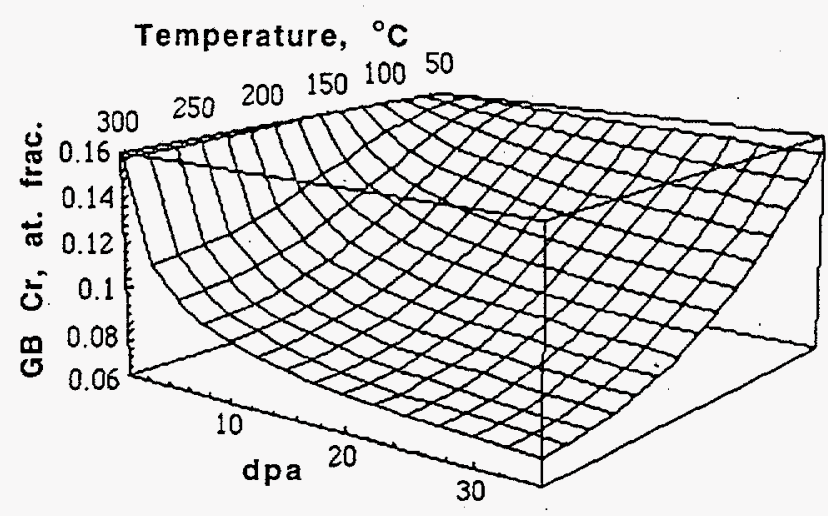

Figure $5 \quad$ Predicted grain boundary $\mathrm{Cr}$ concentration for neutron irradiation for a damage rate of 3 x10-7 dpa/s.

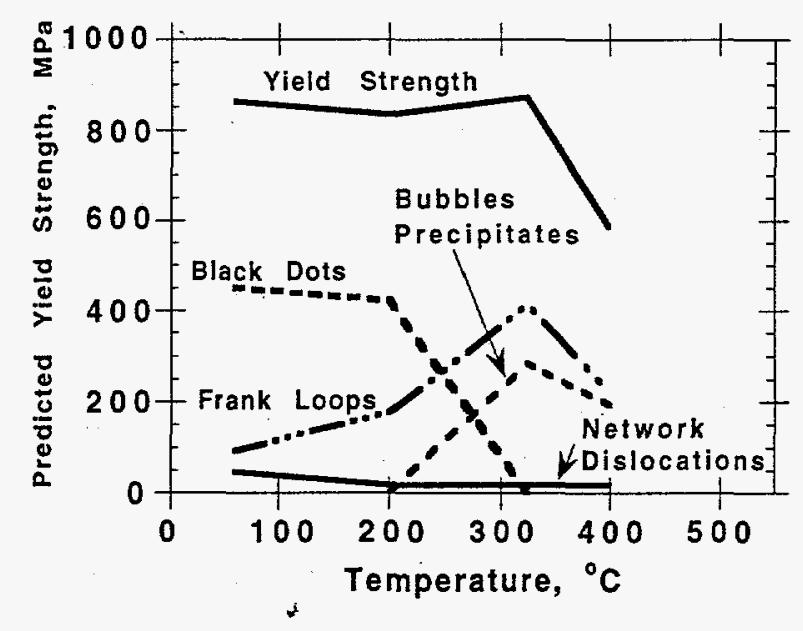

Figure 7 Predicted yield strength contributions from measured components of irradiated microstructure at $7 \mathrm{dpa} .30$ 


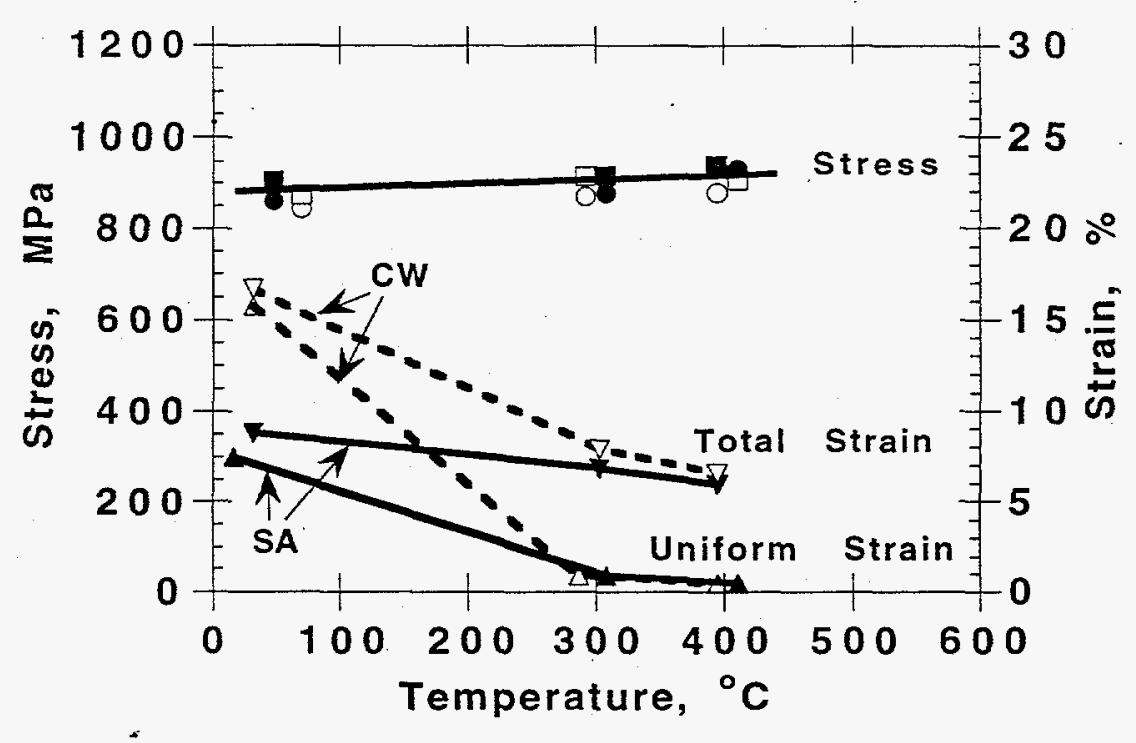

Figure 8 Tensile properties of an irradiated austenitic stainless steel. Open and closed symbols represent solution annealed and cold worked conditions, respectively. Circles indicate yield stress and squares represent ultimate tensile strength. 31

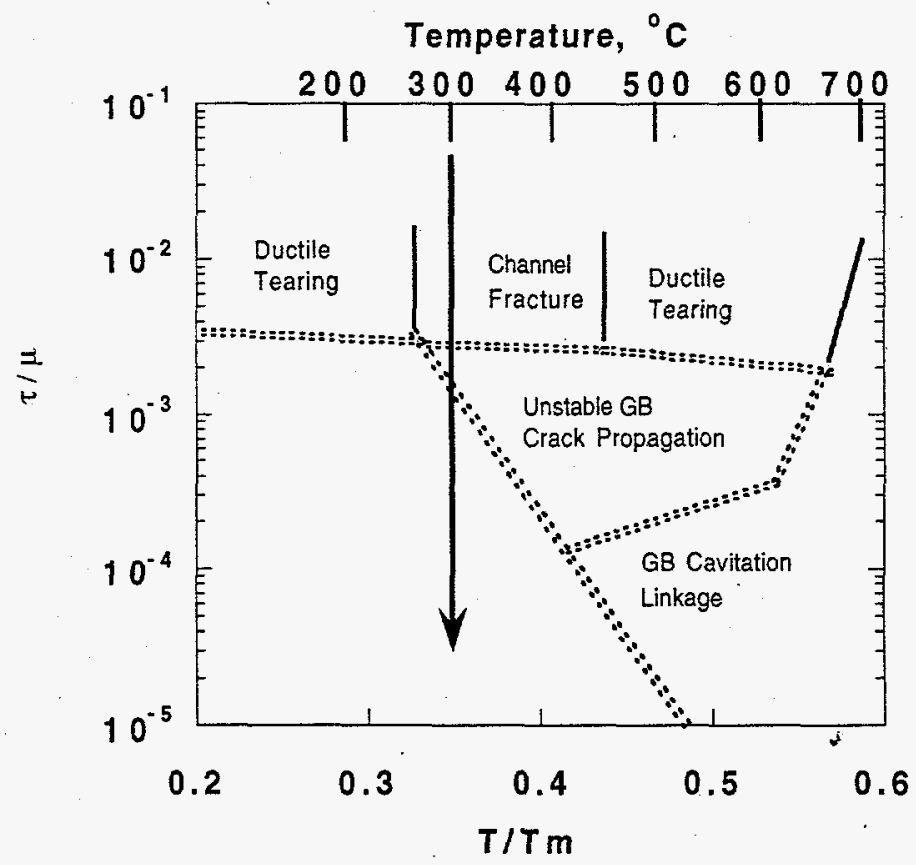

Figure 9 Fracture map as proposed by Bloom. 35 At $300^{\circ} \mathrm{C}$, the fracture mode is expected to change from channel fracture to grain boundary fracture as the stress and strain rate are decreased. The mechanism transitions are shown as a function of normalized shear stress and normalized temperature. 